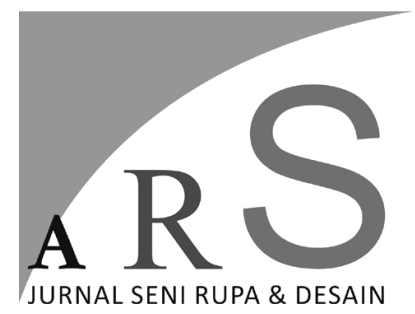

Volume 21 Nomor 3 - Desember 2018

\section{PERSEPSI DESAIN BANTARAN SUNGAI TERHADAP RESIKO LINGKUNGAN DI BANTARAN SUNGAI CODE DAN KARANGWARU RIVER SIDE: STUDI KOMPARASI MAHASISWA AMERIKA SERIKAT DAN INDONESIA}

\author{
Artbanu Wishnu Aji \\ Staf Pengajar Program Studi Desain Interior, Jurusan Desain \\ Fakultas Seni Rupa, Institut Seni Indonesia Yogyakarta \\ E-mail: bau_art@yahoo.com
}

\begin{abstract}
ABSTRAK
Lingkungan bantaran sungai merupakan lingkungan kota yang cukup memiliki resiko bahaya jika dibandingkan dengan wilayah kota lainnya. Resiko bahaya yang muncul dari satu lingkungan tertentu menimbulkan ancaman bagi penghuni wilayah tersebut dan orang-orang yang beraktifitas di sekitarnya. Penelitian ini bertujuan untuk mengukur persepsi resiko lingkungan yang ada di wilayah bantaran sungai Code dan Karangwaru riverside. Metode penelitian menggunakan metode kuantitatif dengan menggunakan angket untuk mengukur tingkat persepsi resiko lingkungan dikalangan mahasiswa desain interior dan arsitektur. 43 responden yang terdiri dari warga negara Indonesia dan Amerika Serikat diminta untuk mengisi angket tentang persepsi resiko lingkungan terhadap dua wilayah bantaran sungai. Hasilnya menunjukkan bahwa kedua wilayah bantaran sungai tersebut secara umum dinilai sedang tingkat keamanannya meskipun masih memiliki resiko banjir dan tanah longsor. Desain bantaran sungai dikedua wilayah tersebut masih dinilai kurang aman bagi anak anak. Resiko dari bahaya polusi dari mengkonsumsi air dan ikan dari wilayah tersebut juga dinilai cukup tinggi. Selain itu desain bantaran sungai kedua wilayah tersebut dinilai memiliki nilai estetika yang baik.
\end{abstract}

Kata Kunci: bantaran sungai, persepsi, resiko lingkungan

\begin{abstract}
Compared to any other areas, riverbank environments are considered hazardous areas in Indoneisan cities. The thread from its environmental hazard can harm any residents who live in that areas. This research aimed to measure perception on environmental risk in the riverbank areas in Code river and karangwaru riverside in Yogyakarta. Using qualitative method, this research targeted 43 university students from United states and Indonesia to rate their enviromental perception toward two different type of riverbank design. The result showed that two types of design were rated as moderate in term of environmental safety. However landslides and floods were percieved as two major threads in those two areas. Both areas were also rated as less safe for childeren. Water pollution and health risk for consuming water from those areas were considered dangerous by respondents. However both areas were perceived as aesthetically pleasing.
\end{abstract}

Keywords: riverbank, perception, environmental risk 


\section{Pendahuluan}

Wilayah di bantaran sungai adalah wilayah yang memiliki potensi bahaya jika dibandingkan dengan wilayah dataran normal. Potensi bahaya ini muncul dari kondisi geografis sungai yang memiliki tebing dan membawa aliran air dari hulu ke hilir. Aliran air yang datang dari hulu seringkali berubah menjadi banjir air bah atau bahkan banjir lahar dingin. Keduanya memiliki daya rusak yang besar seperti meruntuhkan tanggul dan menghanyutkan jembatan.

Sungai di Yogyakarta seperti sungai Code memiliki hulu yang berdekatan dengan gunung Merapi sehingga jika gunung tersebut mengalami erupsi maka material lahar dingin dalam jumlah besar akan terbawa hingga ke hilir. Bencana lahar dingin ini tercatat pernah menghancurkan beberapa jembatan dan tanggul disepanjang aliran sungai Code.

Selain lahar dingin bencana banjir bandang juga sering terjadi jika curah hujan tinggi melanda wilayah Yogyakarta. Meskipun tidak separah banjir lahar dingin banjir bandang ini sering menimbulkan kepanikan dan memaksa penduduk sekitar untuk mengungsi sementara atau membuat tanggul-tanggul darurat sepanjang malam.

Bahaya lain yang muncul dari sungai adalah polusi zat-zat berbahaya. Pemakaian bahan kimia seperti deterjen, pewarna kimia, racun ikan, atau limbah industri dan rumah sakit dapat mencemari air sungai dan berdampak luas di sepanjang aliran sungai tersebut. Meskipun bencana yang ditimbulkan oleh zat kimia ini belum pernah menimbulkan korban jiwa yang besar namun penelitian kandungan polutan kimia di lingkungan sungai sudah mencapai tingkat ambang batas yang bisa ditoleransi oleh manusia.

Perilaku masyarakat yang membuang limbah domestik dan samapah padat ke dalam aliran sungai juga menimbulkan potensi pencemaran. Sampah organik yang busuk akan menimbulkan bakteri yang terbawa oleh aliran sungai sehingga masyarakat yang berinteraksi dengan aliran sungai tersebut dapat terkontaminasi bakteri. Selain sampah kebiasan sebagian masyarakat yang tidak memiliki MCK juga menimbulkan persoalan tersendiri. Selain membawa bakteri e-coli, kotoran yang terbuang juga menimbulakn bau yang mengganggu.

Masyarakat yang mendirikan rumahnya dibibir sungai juga mengalami peningkatan resiko menjadi korban tanah longsor. Talut yang digunakan untuk menahan pondasi rumah seringkali ambrol karena erosi dari aliran sungai sehingga sering kita jumpai rumah yang hanya tinggal bangunan utamanya dan kehilangan separuh dari pondasinya.

Melihat berbagai macam potensi bahaya di atas, wilayah bantaran sungai seharusnya memiliki area bebas dengan jarak aman sekitar 10 meter (PUPR, 2015) dari bibir sungai. Kondisi dilapangan saat ini menunjukkan bahwa masyarakat tetap menghuni rumah rumah yang berada di jalur bahaya. Beberapa upaya pencegahan dilakukan oleh pemerintah dengan membangun pagar pembatas dan perbaikan lingkungan di sekitar bantaran sungai. Tujuan perbaikan lingkungan tersebut adalah untuk meningkatkan kualitas lingkungan di sekitar sungai dan merubah stigma tentang wilayah bantaran sungai yang kumuh dan kotor.

Beberapa upaya perbaikan telah berhasil mengubah kondisi fisik lingkungan menjadi lebih baik seperti di Gondolayu dan Karangwaru (kali buntu). Kedua wilayah tersebut di desain oleh arsitek selaku desainer yang menjadi motor bagi masyarakat sekitar untuk berpartisipasi aktif dalam menata lingkungan. Keberhasilan dua kasus di atas menunjukkan bahwa desain lingkungan memiliki peran dalam meningkatkan citra lingkungan dan menimbulkan persepsi positif.

Paradigma pembangunan sungai saat ini memang masih bertumpu pada perbaikan fisik dan aspek hidrolis sungai. Hal ini menyebabkan nilai-nilai lokal dan konteks seni-budaya menjadi terbaikan dan belum mendapat porsi yang semestinya. Salah satu aspek budaya dalam memahami alam adalah mengetahui potensi dan bahaya yang mungkin timbul di dalamnya. Budaya lokal setempat seperti di lerang merapi menyebut bahaya awan panas sebagai wedhus gembelyang menunjukkan vernakularitas dalam konteks memahami fenomena alam. Di 
lingkungan sungai beberapa istilah seperti lampor juga dikenal sebagai bentuk manifestasi bahaya dari lingkungan gaib sungai.

Upaya untuk memahami konteks budaya dalam mempersepsi bahaya ini diperlukan untuk meningkatkan kualitas perbaikan lingkungan sungai. Konteks yang dilihat secara mendalam akan menimbulkan empati bagi perencana untuk membuat program penataan sungai yang komprehensif. Desainer yang melihat dan mengerti potensi bahaya lingkungan sungai akan memiliki kepekaan untuk menciptakan konsep desain yang mengurangi resiko bahaya tersebut.

Peran perencana dalam desain dan perbaikan kawasan lingkungan sungai telah banyak diteliti, namun persepsi mereka dalam menilai resiko lingkungan masih belum banyak diteliti. Penelitian ini bertujuan untuk melihat persepsi mahasiswa desain interior dalam menilai desain kawasan lingkungan dan perannya dalam mengurangi resiko lingkungan. Selain itu penelitian ini juga akan menjelaskan tentang bahaya apa yang paling dominan di kawasan bantaran sungai dan harus diatasi oleh desainer. Untuk memenuhi tujuan tersebut masalah dalam penelitian ini dirumuskan sebagai berikut :

Bagaimana persepsi mahasiswa desain interior dalam melihat desain kawasan sungai Code (Gondolayu) dan Karangwaru riverside dalam melihat potensi becana dan resiko lingkungan?

\section{Tinjauan Pustaka}

Penelitian yang mengarah pada resiko lingkungan di sekitar sungai dilakukan oleh Bhuiyan et.al (2013: 126-136). Penelitian ini secara spesifik berfokus pada resiko lingkungan dan polusi air sungai-sungai di dunia. Metode yang dilakukan adalah dengan melakukan analisis terhadap penelitian emprik yang telah dilakukan oleh peneliti-peneliti polusi air diseluruh dunia. Hasilnya menunjukkan bahwa sumber pencemaran terbesar disebabkan oleh banyaknya pabrik-pabrik kimia di area hulu dan pembuangan limbah cair dari pusat kota ke wilayah hilir. Penilitian ini tidak melihat persepesi subjek melainkan hanya menganalisis kondisi sungai yang tercemar dan sebab-sebab pencemarannya.
Kajian mengenai perubahan lingkungan fisik dan akibatknya pada pengurangan resiko lingkungan di sungai Code juga pernah dilakukan oleh Nur'aini et.al (2015). Penelitian ini berfokus pada hasil pembangunan dan revitalisasi kawasan bantaran sungai Code. Meskipun tidak mengukur tingkat persepsi masyarakat terhadap keberhasilan revitalisasi tersebut, penelitian ini cukup banyak membahas tentang perubahan pola hidup masyarakat akibat pembangunan fisik yang dilakukan.

Fokus penelitian yang membahas tentang persepsi masyarakat terhadap permukiman di bantaran sungai dilakukan oleh Cesarin dan Ginting (2015). Penilitain ini menggunakan metode survey daring untuk mengumpulkan data tentang persepsi masyarakat umum terhadap permukiman di bantaran sungai. Metode analisis isi digunakan untuk menganalis data yang berisi kata kunci tentang pandangan masyarakat terhadap kawasan tersebut.

Penilitian ini tidak membahas resiko lingkungan yang ada di kawasan bantaran sungai meskipun dari temuan di atas terlihat adanya indikasi tentang resiko-resiko lingkungan seperti pencemaran, pendangkalan dan kerusakan lingkungan. Fokus penelitian hanya mengidentifikasi persepsi terhadap kondisi lingkungan namun tidak melihat hubungan antara kondisi fisik dan persepsi bahaya lingkungan.

Secara umum lingkungan bantaran sungai dipersepsi negatif oleh responden, namun demikian sumber respon negatif tersebut bersumber pada aspek visual yang berhubungan dengan kebersihan dan kerapihan. Respon negatif terhadap bahaya polusi dan banjir kurang dibahas secara mendalam.

Menurut Bohm dan Tanner (2013)secara umum resiko lingkungan ditandai dengan adanya unsur ketidakpastian dan kemungkinan kehilangan ataupun kerugian. Ketidakpastian ini muncul dari hal hal yang tidak terduga seperti banjir bandang ataupun gempa bumi. Selain itu resiko lingkungan juga disebabkan oleh perilaku kelompok masyarakat seperti membuang sampah sembarangan atau memakai bahan-bahan berbahaya tanpa kontrol yang jelas.

Mengatasi bahaya dan resiko lingkungan 
di perkotaan telah menjadi perhatian badanbadan dunia. ADB (Asian Development Bank) memberikan langkah-langkah dalam proses perencanaan kota yang sadar resiko lingkungan dengan tahapan proses sebagai berikut: memahami resiko lingkungan, tata guna lahan untuk mengurangi resiko lingkungan, pengembangan kontrol sebagai alat untuk mereduksi resiko lingkungan, jalur hijau sebagai pencegah bahaya lingkungan, pengembangan ulang perkotaan sebagai strategi untuk mengurangi resiko lingkungan.

Perencanaan dan desain lingkungan yang baik mampu meminimalisir potensi potensi bahaya tersebut. Hal yang perlu dilakukan dalam membuat perencanaan lingkungan sungai yang mampu mereduksi bencana adalah dengan membuat daftar potensi bencana sebagai panduan dan arah pengembangan lingkungan. Proyekproyek pembangunan harus mengacu pada informasi tersebut untuk menghindari kerusakan akibat bencana.

Kerjasama dengan lembaga riset dan universitas juga diperlukan untuk membuat asesmen bencana yang menyeluruh di lingkungan perkotaan yang rawan bencana alam. Dalam kasus kasus hunian informal seperti permukiman liar di bantaran sungai, opsi pemindahan atau relokasi merupakan opsi terakhir yang harus dipertimbangkan secara masak. Pendekatan kultural dan partisipatori desain diperlukan untuk membuat perencanaan rasional dan hemat biaya.

Desainer sebagai pihak yang berpartisipasi aktif dalam pembangunan lingkungan perlu memahami objek desain dengan baik. Tahap ini dikenal sebagai tahap empati (Cross, 2011). Lebih lanjut Cross menjelaskan bahwa tahap ini merupakan tahap pengenalan dan mendekati objek desain dari berbagai sudut sehingga desainer mampu menemukan formulasi masalah dengan tajam. Dalam konteks perbaikan lingkungan sungai, pengenalan terhadap bahaya lingkungan adalah bagian dari empati desainer.

\section{Metode Penelitian}

Penelitian ini menggunakan metode kuantitatif korelasional. Howitt dan Cramer
(Cramer, 2011) menyebutkan bahwa penelitian kuantitatif korelasional adalah jenis penelitian untuk mengetahui hubungan dua variable atau lebih. Meskipun tidak bisa digunakan untuk menentukanhubungansebabakibatdarihubungan dua variabel, penelitian korelasi dapat digunakan untuk menentukan indikasi awal adanya pertautan yang mengindikasikan hubungan sebab akibat. Subjekdalampenelitianiniadalahmahasiswadesain interior dan jurusan lainnya dari Indonesia dan Amerika serikat. Jumlah totalnya 43 orang. Angket ini terdiri dari 3 bagian. Bagian pertama adalah data demografis responden untuk melihat sebaran latar belakang subjek. Bagian kedua adalah kuisioner tentang persepsi bahaya atau resiko lingkungan dan bagian ketiga adalah toleransi bahaya lingkungan yang diterima oleh subjek.

Penelitian ini memiliki dua variabel yaitu persepsi resiko lingkungan mahasiswa dan desain kawasan bantaran sungai. Variabel persepsi resiko lingkungan diukur dengan menggunakan angket persepsi yang akan menentukan rating dan tingkat toleransi bahaya lingkungan yang diterima. Variabel desain lingkungan merupakan bentuk desain kawasan yang dipilih berdasarkan kriteria khusus. Kriteria tersebut antara lain banyaknya perubahan fisik yang diterapkan di kawasan tersebut dan fungsi perubahan fisik tersebut dalam mencegah potensi bahaya yang mungkin terjadi.

Pemilihan sampel penelitian dilakukan secara acak atau random sampling untuk menghasilkan data yang bersifat umum. Subjek akan diberi angket dan diminta untuk memberikan jawaban melalui pilihan jawaban yang tersedia. Angket akan dibagikan secara langsung kepada responden dan dikembalikan setelah semua pertanyaan angket terjawab. Setelah semua data terkumpul, analisis dilakukan dengan menggunakan bantuan perangkat lunak SPSS 17 (program aplikasi bisnis yang berguna untuk menganalisa data statistik: Predictive Analytics SoftWare). Hasil analiisis ini berupa frekuensi dari demografi responden seperti jenis kelamin, semester dan daerah asal. Selain itu analisis ini juga akan menghasilkan rating desain bantaran sungai yang dinilai mampu untuk mengatasi bahaya lingkungan. Tingkat toleransi 
subjek juga akan muncul dari hasil analisis SPSS yang menunjukkan bahaya apa yang bisa diterima dan yang sulit untuk diterima.

Hasil analisis kemudian diinterpertasi dan dibahas dengan melihat jenis dan hasil-hasil penelitian terdahulu sehingga tercipta diskusi wacana dalam pembahasannya. Pembahasan ini akan memperkaya bidang penelitian resiko lingkungan dengan memberikan kontribusi temuan terbaru dan hubungan dialognya dengan penelitian sebelumnya. Analisis data dilakukan dengan bantuan perangkat lunak SPPS 17. Analisis korelasional dilakukan untuk melihat hubungan antara gender, umur, tingkat semester, hubungan dengan sungai dan persepsi mereka terhadap resiko lingkungan dan tingkat toleransinya.

\section{Hasil Dan Pembahasan}

Hasil Pengumpulan datayang dilakukan dengan menggunakan kuisioner untuk mengukur persepsi mahasiswa terhadap desain bantaran sungai Code dan Karangwaru riverside menghasilkan beberapa luaran dalam tabel di bawah ini.

Tabel 1. Demografi Responden
Tabel di atas menunjukkan bahwa reponden perempuan lebih dominan dibandingkan dengan responden laki-laki dengan perbandingan rasio prosentase $74,4 \%$ dan 20,9\%. Selain itu asal negara responden lebih banyak yang berasal dari Amerika Serikat (US) dibandingkan dengan responden yang berasal dari Indonesia. Rasio perbandingan untuk asal kebangsaan ini adalah 69,8 \% dan 27,9\% satu responden tidak menjawab asal kebangsaannya. Data di atas menggambarkan perspektif utama responden yang kebanyakan adalah perempuan dan berasal dari Amerika serikat.

Tabel 2 menunjukkan nilai rerata persepsi responden terhadap dua bantaran sungai dan resiko lingkungan yang ditimbulkannya. Tabel tersebut menunjukkan bahwa secara umum responden melihat bahwa kondisi kedua wilayah bantaran sungai tersebut terlihat baik secara estetis. Hal ini terlihat pada nilai rerata untuk item "opini estetis " yang mencapai angka 3,58 ( tabel 2). Nilai ini berarti di atas nilai tengah (nilai tengah memiliki nilai 3) dan memiliki kecenderungan untuk dipersepsi baik. Tiga item yang berhubungan dengan kulaitas lingkungan secara estetis yaitu " opini estetis", "lingkungan

Jenis Kelamin

\begin{tabular}{llrrrr}
\hline \hline & & & & \multicolumn{2}{c}{ Cumulative } \\
& & Frequency & Percent & Valid Percent & Percent \\
\hline Valid & 0 & 2 & 4,7 & 4,7 & 4,7 \\
& laki laki & 9 & 20,9 & 20,9 & 25,6 \\
& Perempuan & 32 & 74,4 & 74,4 & 100,0 \\
& Total & 43 & 100,0 & 100,0 & \\
\hline \hline
\end{tabular}

Kebangsaan

\begin{tabular}{llrrrr}
\hline \hline & & & & \multicolumn{2}{c}{ Cumulative } \\
& & Frequency & Percent & Valid Percent & Percent \\
\hline Valid & 0 & 1 & 2,3 & 2,3 & 2,3 \\
& US & 30 & 69,8 & 69,8 & 72,1 \\
& Indonesia & 12 & 27,9 & 27,9 & 100,0 \\
& Total & 43 & 100,0 & 100,0 & \\
\hline \hline
\end{tabular}


sungai" dan "total kualitas" memiliki nilai rerata di atas 3 yang memberikan gambaran bahwa responden melihat kedua bantaran sungai tersebut baik dari segi estetika.

Sayangnya kualitas positif ini juga diikuti dengan persepsi negatif tentang kualitas air sungai. Item yang berhubungan dengan "polusi air" menunjukkan nilai rerata yang cukup tinggi yaitu 3,63 yang berarti responden melihat kualitas air secara umum tercemar cukup parah. Kualitas negatif lain adalah kemungkinan bahaya longsor yang memiliki nilai 2,86. Angka tersebut masih dibawah angka 3 namun demikian nilainya cukup tinggi jika dilihat dari persepsi negatif lainnya seperti "potensi bahaya" $(1,86)$ dan "potensi banjir”. $(2,40)$

Persepsi terhadap buruknya kualitas air ini juga terlihat dari nilai rerata pemanfaatan sungai (tabel 2) yang terdiri dari item "kesedian minum air", "minum setelah masak" dan "makan ikan". Nilai rerata dari ketiga item tersebut di bawah angka 3 yang menunjukkan bahwa responden sangat enggan untuk memanfaatkan air dan ikan yang ada dikedua sungai tersebut.
Perbedaan persepsi berdasarkan asal kebangsaan dapat dilihat di tabel 3. Hal yang menarik adalah responden dari Amerika melihat potensi bahaya di kedua bantaran sungai tersebut lebih rendah $(1,47)$ jika dibandingkan dengan responden asal Indonesia $(2,83)$. Hal ini kemungkinan disebabkan oleh pengalaman responden asal Indonesia yang mengetahui bahwa sungai tersebut seringkali memiliki potensi bahaya seperti kecelakaan ataupun kejadian seperti tenggelam yang menimbulkan korban meninggal.

Hal lain yang menarik untuk dicermati adalah responden dari Amerika dan Indonesia hampir memiliki persepsi yang sama tentang tingkat keamanan bantaran sungai bagi anak anak nilai rerata untuk masing masing asal kebangsaan adalah 2,77 (US) dan 2,75 (Indonesia ). Nilai ini memiliki arti kurang aman bagi anak anak karena batas nilai keamanan adalah 3 .

Tabel 2. Nilai Rerata Persepsi Resiko Lingkungan Secara Umum

Descriptive Statistics

\begin{tabular}{lrrrrrrrr}
\hline \hline & $\mathrm{N}$ & Range & Minimum & Maximum & Sum & Mean & Std. Deviation & Variance \\
\hline Potensi Bahaya & 43 & 4 & 1 & 5 & 80 & 1,86 & 1,060 & 1,123 \\
Potensi Banjir & 43 & 4 & 1 & 5 & 103 & 2,40 &, 929 &, 864 \\
Potensi Longsor & 43 & 4 & 1 & 5 & 123 & 2,86 &, 861 &, 742 \\
Polusi Air & 43 & 4 & 1 & 5 & 156 & 3,63 &, 976 &, 953 \\
Kesedian Minum & 43 & 2 & 1 & 3 & 51 & 1,19 &, 450 &, 203 \\
Minum stlh masak & 43 & 4 & 0 & 4 & 99 & 2,30 & 1,013 & 1,025 \\
Makan ikan & 43 & 4 & 1 & 5 & 92 & 2,14 & 1,037 & 1,075 \\
aman utk anak & 43 & 4 & 1 & 5 & 120 & 2,79 & 1,146 & 1,312 \\
Binatang liar & 43 & 3 & 1 & 4 & 114 & 2,65 &, 948 &, 899 \\
keamanan reling & 43 & 4 & 1 & 5 & 133 & 3,09 & 1,306 & 1,705 \\
opini estestis & 43 & 5 & 0 & 5 & 154 & 3,58 & 1,096 & 1,202 \\
lingkungan sungai & 43 & 4 & 1 & 5 & 155 & 3,60 &, 877 &, 769 \\
total qualitas & 43 & 4 & 1 & 5 & 157 & 3,65 &, 923 &, 852 \\
Valid N (listwise) & 43 & & & & & & & \\
\hline \hline
\end{tabular}


Tabel 3. Perbandingan Nilai Rerata Antara Responden Amerika dan Indonesia

Group Statistics

\begin{tabular}{|c|c|c|c|c|c|}
\hline & Kebangsaan & $\mathrm{N}$ & Mean & Std. Deviation & Std. Error Mean \\
\hline \multirow[t]{2}{*}{ Potensi Bahaya } & US & 30 & 1,47 &, 629 & ,115 \\
\hline & Indonesia & 12 & 2,83 & 1,337 & ,386 \\
\hline \multirow[t]{2}{*}{ Potensi Banjir } & US & 30 & 2,33 &, 844 &, 154 \\
\hline & Indonesia & 12 & 2,58 & 1,165 &, 336 \\
\hline \multirow[t]{2}{*}{ Potensi Longsor } & US & 30 & 2,83 & ,913 & , 167 \\
\hline & Indonesia & 12 & 3,00 & ,739 & ,213 \\
\hline \multirow[t]{2}{*}{ Polusi Air } & US & 30 & 3,80 &, 805 & , 147 \\
\hline & Indonesia & 12 & 3,08 & 1,165 &, 336 \\
\hline \multirow[t]{2}{*}{ Kesedian Minum } & US & 30 & 1,10 &, 305 &, 056 \\
\hline & Indonesia & 12 & 1,42 & ,669 & , 193 \\
\hline \multirow[t]{2}{*}{ Minum stlh masak } & US & 30 & 2,53 & ,937 & , 171 \\
\hline & Indonesia & 12 & 1,83 & 1,030 & ,297 \\
\hline \multirow[t]{2}{*}{ Makan ikan } & US & 30 & 2,13 & 1,106 & ,202 \\
\hline & Indonesia & 12 & 2,17 &, 937 & ,271 \\
\hline \multirow[t]{2}{*}{ aman utk anak } & US & 30 & 2,77 & 1,194 & ,218 \\
\hline & Indonesia & 12 & 2,75 & 1,055 &, 305 \\
\hline \multirow[t]{2}{*}{ Binatang liar } & US & 30 & 2,77 & ,935 & ,171 \\
\hline & Indonesia & 12 & 2,33 & ,985 & ,284 \\
\hline \multirow[t]{2}{*}{ keamanan reling } & US & 30 & 3,50 & 1,225 &, 224 \\
\hline & Indonesia & 12 & 2,00 &, 853 & ,246 \\
\hline \multirow[t]{2}{*}{ opini estestis } & US & 30 & 3,67 & 1,155 & ,211 \\
\hline & Indonesia & 12 & 3,50 & ,905 & ,261 \\
\hline \multirow[t]{2}{*}{ lingkungan sungai } & US & 30 & 3,73 & ,785 & ,143 \\
\hline & Indonesia & 12 & 3,25 & 1,055 & ,305 \\
\hline \multirow[t]{2}{*}{ total qualitas } & US & 30 & 3,83 &, 791 & , 145 \\
\hline & Indonesia & 12 & 3,17 & 1,115 &, 322 \\
\hline
\end{tabular}

Responden dari Amerika pada umumnya menilai kualitas estetis lingkungan bantaran sungai di kedua tempat tersebut baik. Hal menarik yang perlu dicermati adalah persepsi estetika mereka lebih tinggi dibandingkan dengan persepsi estetis responden asal Indonesai. Hal ini kemungkinan disebabkan faktor kebaruan atau Novelty yang dialami oleh responden asal Amerika. Lingkungan bantaran sungai tersebut memiliki daya tarik estetis karena merupakan lingkungan yang berbeda dengan yang mereka lihat sehari hari. Bagi responden asal Indonesia kedua bantaran sungai tersebut merupakan pemandangan yang cukup lazim, meskipun dari sisi penataan memiliki keunikan jika dibandingkan lingkungan bantaran sungai lainnya.

Tabel 3 juga menunjukkan perbedaan persepsi terhadap polusi air antara responden dari Amerika (3,80) dan Indonesia (3,08). Hal ini menunjukkan bahwa responden dari Amerika menilai bahwa air di kedua sungai tersebut lebih tercemar jika dibandingkan responden dari Indonesia. Perbedaan ini kemungkinan disebabkan faktor kepekaan lingkungan yang berbeda. Responden dari Indonesia melihat kualitas sungai di Indonesia secara umum sama yaitu kotor dan tercemar sehingga mereka menilai dengan angka 3, 08. Responden dari Amerika kemungkinan membadingkan kualitas air sungai tersebut dengan kualitas air sungai di negaranya. Meskipun sungai sungai di negara industri pada umumnya tercemar limbah industri, upaya upaya pembersihan juga dilakukan dengan bertahap dan terus-menerus sehingga terlihat perbaikan kualitas air sungai-sungai tersebut. Perbedaan persepsi dapat pula ditimbulkan dari perbedaan 
budaya dimana banyak masyarakat Indonesia yang membuang hajatnya langsung ke sungai dan menimbulkan bau tidak sedap di sekitar lingkungan sungai.

Air yang sudah dimasak dari kedua sungai tersebut dipersepsi berbeda oleh kedua kelompok responden. Responden dari Amerika memiliki persepsi lebih positif terhadap air sungai yang telah dimasak $(2,53)$. Angka ini merupakan peningkatan dari angka 1,10 yaitu ketika air sungai tersebut belum dimasak (Tabel 3). Peningkantan angka ini lebih besar jika dibandingkan dengan responden dari Indonesia yang hanya meningkat dari angka 1,42 (sebelum dimasak) menjadi 1,83 (setelah dimasak). Responden dari Indoesia melihat bahwa memasak air sungai tidak merubah persepsi mereka menjadi postif meskipun terdapat peningkatan angka persepsi.
Perbedaan persepsi berdasar jenis kelamin dapat dilihat di tabel 4 di atas. Tabel tersebut menunjukkan bahwa responden laki-laki menilai kualitas estetis di kedua sungai tersebut lebih tinggi dibandingkan dengan responden perempuan. Secara umum baik kelompok responden lakilaki maupun kelompok responden perempuan menilai bahwa kualitas estetis lingkungan kedua sungai terbilang cukup baik. Hal ini terlihat dari nilai rerata di item penilaian "opini estetis", "lingkungan sungai" dan "total qualitas" yang memiliki nilai diatas 3 .

Perbedaan persepsi yang mencolok juga terlihat di item-item yang berhubungan dengan potensi bahaya. Responden perempuan menilai potensi bahaya lebih tinggi dibandingkan dengan responden laki-laki (tabel 4).

Tabel 4. Tabel Nilai Rerata Persepsi Bantaran Sungai Antara Responden Laki-laki dan Perempuan

Group Statistics

\begin{tabular}{|c|c|c|c|c|c|}
\hline & "Jenis Kelamin & $\overline{\mathrm{N}}$ & Mean & Std. Deviation & Std. Error Mean \\
\hline \multirow[t]{2}{*}{ Potensi Bahaya } & laki laki & 9 & 1,22 & ,441 & ,147 \\
\hline & Perempuan & 32 & 2,03 & 1,150 & ,203 \\
\hline \multirow[t]{2}{*}{ Potensi Banjir } & laki laki & 9 & 2,89 & ,782 & ,261 \\
\hline & Perempuan & 32 & 2,28 & , 958 & , 169 \\
\hline \multirow[t]{2}{*}{ Potensi Longsor } & laki laki & 9 & 3,11 & ,782 & ,261 \\
\hline & Perempuan & 32 & 2,84 & ,884 & , 156 \\
\hline \multirow[t]{2}{*}{ Polusi Air } & laki laki & 9 & 3,33 & 1,118 & , 373 \\
\hline & Perempuan & 32 & 3,69 & ,931 & , 165 \\
\hline \multirow[t]{2}{*}{ Kesedian Minum } & laki laki & 9 & 1,22 & ,441 & , 147 \\
\hline & Perempuan & 32 & 1,19 & ,471 & ,083 \\
\hline \multirow[t]{2}{*}{ Minum stlh masak } & laki laki & 9 & 2,11 & 1,167 & ,389 \\
\hline & Perempuan & 32 & 2,44 & ,948 & 168 \\
\hline \multirow[t]{2}{*}{ Makan ikan } & laki laki & 9 & 1,67 & 1,000 & ,333 \\
\hline & Perempuan & 32 & 2,31 & 1,030 & ,182 \\
\hline \multirow[t]{2}{*}{ aman utk anak } & laki laki & 9 & 2,78 & 1,563 &, 521 \\
\hline & Perempuan & 32 & 2,75 & 1,047 & 185 \\
\hline \multirow[t]{2}{*}{ Binatang liar } & laki laki & 9 & 2,44 & 1,236 & ,412 \\
\hline & Perempuan & 32 & 2,69 & , 896 & ,158 \\
\hline \multirow[t]{2}{*}{ keamanan reling } & laki laki & 9 & 3,56 & ,726 & ,242 \\
\hline & Perempuan & 32 & 2,94 & 1,435 & ,254 \\
\hline \multirow[t]{2}{*}{ opini estestis } & laki laki & 9 & 3,78 & ,972 &, 324 \\
\hline & Perempuan & 32 & 3,59 & 1,132 & ,200 \\
\hline \multirow[t]{2}{*}{ lingkungan sungai } & laki laki & 9 & 3,78 & ,667 & ,222 \\
\hline & Perempuan & 32 & 3,56 & ,948 & , 168 \\
\hline \multirow[t]{2}{*}{ total qualitas } & laki laki & 9 & 4,00 & ,707 & ,236 \\
\hline & Perempuan & 32 & 3,56 & ,982 & ,174 \\
\hline
\end{tabular}


Tabel 5. Tabel Nilai Rerata Persepsi Bantaran Sungai Berdasarkan Lokasi

Group Statistics

\begin{tabular}{|c|c|c|c|c|c|}
\hline & Lokasi & $\mathrm{N}$ & Mean & Std. Deviation & Std. Error Mean \\
\hline \multirow[t]{2}{*}{ Potensi Bahaya } & Kali Code & 17 & 2,59 & 1,228 & ,298 \\
\hline & Karangwaru & 26 & 1,38 &, 571 & ,112 \\
\hline \multirow[t]{2}{*}{ Potensi Banjir } & Kali Code & 17 & 2,76 & 1,033 & ,250 \\
\hline & Karangwaru & 26 & 2,15 & ,784 & ,154 \\
\hline \multirow[t]{2}{*}{ Potensi Longsor } & Kali Code & 17 & 3,24 & 1,033 & ,250 \\
\hline & Karangwaru & 26 & 2,62 & ,637 & ,125 \\
\hline \multirow[t]{2}{*}{ Polusi Air } & Kali Code & 17 & 3,94 & ,899 & ,218 \\
\hline & Karangwaru & 26 & 3,42 & ,987 & ,194 \\
\hline \multirow{2}{*}{ Kesedian Minum } & Kali Code & 17 & 1,18 & ,393 & ,095 \\
\hline & Karangwaru & 26 & 1,19 & ,491 &, 096 \\
\hline \multirow[t]{2}{*}{ Minum stlh masak } & Kali Code & 17 & 2,18 & 1,074 & ,261 \\
\hline & Karangwaru & 26 & 2,38 & ,983 & ,193 \\
\hline \multirow[t]{2}{*}{ Makan ikan } & Kali Code & 17 & 1,94 & 1,029 & ,250 \\
\hline & Karangwaru & 26 & 2,27 & 1,041 & ,204 \\
\hline \multirow[t]{2}{*}{ aman utk anak } & Kali Code & 17 & 2,59 & 1,228 & ,298 \\
\hline & Karangwaru & 26 & 2,92 & 1,093 & ,214 \\
\hline \multirow[t]{2}{*}{ Binatang liar } & Kali Code & 17 & 3,00 & ,707 & ,171 \\
\hline & Karangwaru & 26 & 2,42 & 1,027 & ,201 \\
\hline \multirow[t]{2}{*}{ keamanan reling } & Kali Code & 17 & 2,88 & 1,111 & ,270 \\
\hline & Karangwaru & 26 & 3,23 & 1,423 & ,279 \\
\hline \multirow[t]{2}{*}{ opini estestis } & Kali Code & 17 & 3,12 & 1,317 & ,319 \\
\hline & Karangwaru & 26 & 3,88 & ,816 & ,160 \\
\hline \multirow[t]{2}{*}{ lingkungan sungai } & Kali Code & 17 & 3,12 & ,993 & ,241 \\
\hline & Karangwaru & 26 & 3,92 & ,628 & ,123 \\
\hline \multirow[t]{2}{*}{ total qualitas } & Kali Code & 17 & 3,00 & 1,061 & ,257 \\
\hline & Karangwaru & 26 & 4,08 & ,484 & ,095 \\
\hline
\end{tabular}

Perbedaan persepsi berdasarkan lokasi dapat dilihat dari tabel 5 di atas. Karangwaru riverside $(3,88)$ dinilai lebih estetis jika dibandingkan dengan Kali Code $(3,12)$. Meskipun secara historis Kali Code di desain oleh arsitek YB Mangunwijaya dan memiliki daya tarik estetika tersendiri, responden yang mayoritas berasal dari Amerika melihat bahwa kondisi actual Kali Code saat ini tidak sebagus Karangwaru riverside.

Kali code juga dilihat sebagai lingkungan yang memiliki ancaman dari munculnya binatang liar yang terlihat dari nilai rerata 3. Angka ini lebih tinggi jika dibandingkan dengan karangwaru yang memiliki nilai 2,42.

\section{Kesimpulan}

Secara umum desain kawasan bantaran sungai Code dan Karangwaru memiliki memiliki perbedaan tingkat persepsi dalam menghadapi potensi bahaya yang dicerap oleh responden. Tingkat resiko di lingkungan bantaran sungai Code dan karangwaru riverside tergolong sedang. $\mathrm{Hal}$ ini terlihat dari nilai rerata untuk ketiga item yang berhubungan dengan bahaya seperti banjir dan tanah longsor. Nilai rerata untuk item-item tersebut ada dibawah 3 yang berarti dinilai sebagai "cukup aman". Namun demikian meskipun kedua bantaran sungai telah memiliki talud penahan di sisi kanan dan kirinya responden tetap menilai potensi longsor masih mungkin terjadi terutama di wilayah kali Code.

Ancaman terbesar menurut responden ada pada potensi ancaman bahaya polusi air sedangkan ancaman tanah longsor menempati urutan bahaya kedua. Potensi banjir menempati urutan ketiga. Penggunaan reling pada sisi 
bantaran sungai dinilai cukup aman oleh responden namun secara umum responden juga melihat bahwa lingkungan tersebut tidak cukup aman bagi anak-anak. Reling tersebut kemungkinan aman bagi orang dewasa tetapi dinilai tidak melindungi anak dari kemungkinan jatuh. Polusi dan pencemaran air juga memiliki persepsi buruk dikalangan responden. Mereka pada umumnya menolak untuk mengkonsumsi air dan ikan yang ada dikedua sungai tersebut. Khusus untuk pencemaran air sungai code memiliki persepsi pencemaran lebih tinggi jika dibandingkan dengan karangwaru riverside. $\mathrm{Hal}$ ini kemungkinan disebabkan karena sungai Code masih menagggung beban limbah domestik yang dialirkan langsung ke sungai sehingga substansi pencemar dapat terlihat langsung oleh responden.

\section{Daftar Pustaka}

Bhuiyan, Abdul Bashor et.al(2013) The Environmental Risk And Water Pollution: AReview From The River Basins Around TheWorld.American-Eurasian Journal of Sustainable Agriculture
Bohm dan Tanner dalam Linda Steg, Agnes E. Van Den Berg and Judith I.M De Groot. (2013). Enviromental Psychology an Introduction. West Suxxes: BPS Blackwell.

Cesarin, Binar T dan Ginting, Chorina (2015). Persepsi Masyarakat terhadap Permukiman Bantaran Sungai. Prosiding Temu Ilmiah IPLBI 2015 Jurusan Arsitektur, FakultasTeknik, Universitas Sam Ratulangi

Cross, Nigel (2011) Design Thinking: Understanding How Designer Think and Work, New York. Berg, Oxford

Dennis Howitt and Duncan Cramer. (2011). Introducing to Reasearch Method in Psychology. London: Pearson.

Nur'aini, Dewi Ratna et.al (2015). Kajian Revitalisasi Arsitektural di Bantaran Kali Code Yogyakarta. Jurnal Fakultas Teknik Universitas Muhammadiyah Jakarta

Peraturan Menteri Pekerjaan Umum dan Perumahan Rakyat tahun 2015 Nomor 28/ PRT/M/2015, tentang Penetapan Garis Sempadan Sungai dan Garis Sempadan Danau 